\title{
Maize production in mid hills of Nepal: from food to feed security
}

\author{
${ }^{1}$ Krishna Prasad Timsina*, ${ }^{1}$ Yuga Nath Ghimire, and ${ }^{2}$ Jeevan Lamichhane \\ ${ }^{1}$ Socio-Economics and Agricultural Policy Research Division \\ Khumaltar, Lalitpur, Nepal \\ ${ }^{2}$ Regional Agricultural Research Station, Khajura, Banke \\ Nepal Agricultural Research Council (NARC) \\ *Corresponding author email: krishnatimsina2000@gmail.com
}

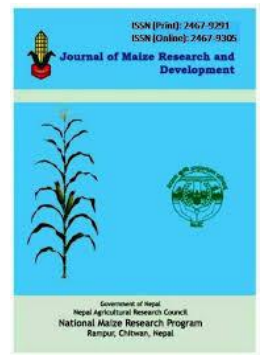

Received: September 2016; Revised: October 2016; Accepted: November 2016

\begin{abstract}
This study was undertaken in 2016 to analyze the production and utilization of maize in Nepal. Sixty maize growers from Kavre and Lamjung districts were selected using purposive, cluster and simple random sampling techniques. Similarly, six feed industries and five maize experts from Chitwan district were also interviewed. Study shows $56 \%$ of the total areas were used for maize production and $50 \%$ of the maize areas were covered by hybrid maize. There was no practice of contract maize production. The results revealed that $60 \%, 25 \%$ and $3 \%$ of the grain were used for animal feed, food and seed respectively in hill districts. Whereas the remaining amount of the maize (12\%) was sold to the different buyers. The proportion of maize feed supply to different animals in the study area was varying. Result shows that at least 1.5 million tons of maize is required only to the feed industries affiliated with national feed industry association in Nepal. Similarly, out of total maize used in feed production, $87 \%$ of the maize was imported from India each year by feed industries. Analysis shows negative correlation between scale of feed production and use of domestic maize due to unavailability of required quantity of maize in time. The major pre-condition of feed industries for maize buying was moisture content which must be equal or less than $14 \%$. Very little or no inert materials and physical injury, free from fungal attack and bigger size were also the criteria for maize buying. However, some of the feed industries were also thinking about protein and amino acid contents. Result shows 13\% and 8.5\% increasing demand of poultry feed and animal feed, respectively over the last five year in Nepal. Most likely, maize is known as a means of food security in Nepal, however, in the context of changing utilization patterns at the farm level and also tremendous increasing demand of maize at the industry level suggest to give more focus on development and dissemination of maize varieties that can contribute to the feed security issues as well.
\end{abstract}

Key words: Maize, feed security, food security, utilization pattern, food habit

Correct citation: Timsina, K.P., Ghimire, Y.N., \& Lamichane, J. (2016). Maize production in mid hills of Nepal: from food to feed security. Journal of Maize Research and Development, 2 (1): 20-29, doi: http://dx.doi.org/10.3126/jmrd.v2i1.16212 
Journal of Maize Research and Development (2016) 2 (1): 20-29

ISSN: 2467-9291 (Print), 2467-9305 (Online)

DOI: http://dx.doi.org/10.3126/jmrd.v2i1.16212

\section{INTRODUCTION}

Maize (Zea mays L.) is main crop after Rice in Nepal in term of area and production (MOAD, 2015). Ranum et al. (2014) reported that $98 \mathrm{~g} / \mathrm{person} /$ day were the per capita maize consumption in Nepal, which was the highest in the South Asia. It is a principal food crop of the hilly farmers and source of animal feed for different feed industries in Terai region of Nepal (KC et al., 2015). In the hills of Nepal, more than $86 \%$ maize production has been used for human consumption and $80 \%$ maize production in the Terai is used for poultry and animal feed (Gurung et al., 2011). The farm level yield of maize $(2.45 \mathrm{t} / \mathrm{ha})$ is not satisfactory as compared to attainable yield (5.7 t/ha) in Nepal (MOAD, 2014; KC et al., 2015). Similarly, the seed replacement rate is also low in maize (11.3\%) in Nepal (Pokharel, 2013). It is reported that the demand for maize has been growing by $5 \%$ over the last decade (Sapkota \& Pokhrel, 2010). It is also reported that about 0.5 million ton feed has been produced annually in Nepal by the 114 feed industries. However, the feed demand is increasing at the rate $11 \%$ per annum (CDD, 2011). There was about 40-45\% of maize import from India every year (Bhattarai, 2011). But there is gradual decrease in import of maize in recent years. MOAD/CBS reported that the Maize import dependency ratio has decreased by $11 \%$ over the period from 2008-2014. KC et al. (2015) reported that there is shifting in demand from food to feed for livestock and poultry in Nepal. It has been observed the increasing trends of consuming more quantity of protein and micro-nutrient rich food items in Nepal in the recent days compared to last decades (MOAD/CBS, 2016). Until 2016, NARC has developed 30 varieties of maize (NMRP, 2015; NMRP, 2013; NARC, 2016). Out of 30 varieties, 5 were hybrids (Gaurab, Khumal Hybrid-2, Rampur Hybrid-2, Rampur Hybrid-4 and Rampur Hybrid-6) and 6 were de-notified (Makalu-2, Janaki, Sarlahi Seto, Hetauda Composite, Kakani Pahelo and Rampur Pahelo) (NMRP, 2015). In addition, 34 imported hybrids of maize were registered in Nepal (NMRP, 2013). In this context, we are interested to look at the production and utilization pattern of maize in hills of Nepal in changing context of food to feed security.

\section{MATERIALS AND METHODS}

\section{Selection of Study Sites and Sample}

At the first stage, Kavre and Lamjung districts were selected purposely based on potentiality of maize production to represent hills ecology in the central and western development region respectively. After consultation with officials from respective Agricultural Development offices, Kashikhanda pocket from Kavre and Ramgha pocket from Lamjung were selected. Then, 30 farmers were selected randomly from each pocket. Six feed industries were selected randomly from Chitwan district to represent major maize production districts and major hub of feed industries in the country.

\section{Techniques used in data collection and analysis}

Desk reviews were undertaken to understand maize production and their utilization patterns in Nepal. Survey was conducted with different feed industries to analyze different aspects 
such as the feed production, raw materials utilization, demand trend of feed for different animals etc. Expert consultation meeting was done at each proposed districts with DADO officials and other experts in the districts. In case of households and feed industries survey, face to face interview were done using semi-structured questionnaire. After collecting the data, it was compiled, reviewed and cleaned before final analysis for the accuracy of the results. This study used both descriptive statistics as well as inferential statistics. In case of inferential statistics, independent samples T-test was used to analyze the average maize yield, hybrid yield and per farm production of maize in the sample.

\section{RESULTS AND DISCUSSION}

\section{Maize Research and production environment}

Average land holding size in the study area was 0.50 ha, that is lower than national average which is 0.68 ha $(\mathrm{MOAD}, 2015)$. About $56 \%$ of the total area was used for maize production; this percentage was a higher in Kavre compared to Lamjung district. Twenty seven per cent farmers in the study area were using only hybrid seed. It is higher in Kavre (44\%) than in Lamjung district (9\%). In totality, $50 \%$ of the maize areas were covered by hybrid maize in the study area. The percentage of hybrid coverage was far higher in Kavre (70\%) than in Lamjung district (13\%). One third of the farmers in the study area were using both hybrid and improved seed (Table 1). CDD (2011) reported that about $71 \%$ of land is utilized for hybrid maize cultivation in Kavre by the maize mission participating farmers. Out of 25 improved varieties of maize released by NWRP, only 3 (Deuti, Rampur composite and Arun-2) were found in the field. Clear cut mandate to research and extension is required for integration/packaging of technology generated from NARC, which is utmost necessary for further up scaling of technology (Timsina et al., 2016c). Study shows none of the farmers in Lamjung were using Deuti variety; they were using Rampur composite, Arun-2 and other own saved seed which they were unable to tell the name of varieties (Figure 1). Paudyal (2001); Lamichhane et al. (2015) reported the decreasing trend of local maize varieties in mid hills of Nepal. Rampur Composite, Arun 2 and Manakamana 6 are improved varieties popular in the western hills of Nepal (Lamichhane et al., 2015). 


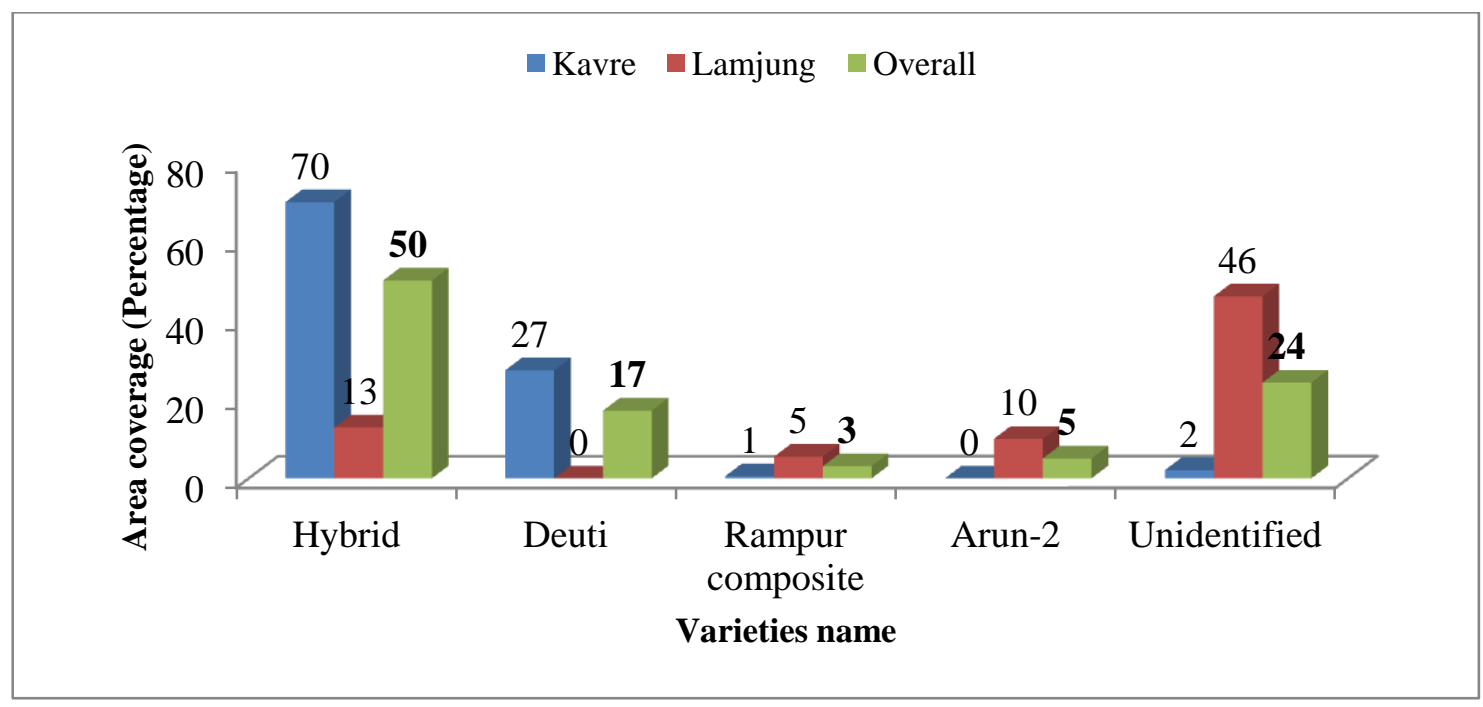

Figure 1. Coverage of different maize varieties in the study area.

Table 1: Description of maize production environment in the study area.

\begin{tabular}{llll}
\hline Description & \multicolumn{2}{c}{ Study area } \\
\cline { 2 - 4 } & $\begin{array}{l}\text { Kavre } \\
(\mathrm{n}=30)\end{array}$ & $\begin{array}{l}\text { Lamjung } \\
(\mathrm{n}=30)\end{array}$ & $\begin{array}{l}\text { Overall } \\
(\mathrm{n}=60)\end{array}$ \\
\hline $\begin{array}{l}\text { Average land holding (ha) } \\
\text { Land allocated for maize production per farm }\end{array}$ & 0.59 & 0.34 & 0.44 \\
(ha) & & 0.20 & 0.50 \\
Farmers using hybrid maize only (\%) & 44 & 9 & 27 \\
Farmers using improved variety only (\%) & 16 & 66 & 40 \\
Farmers using both hybrid and improved & 40 & 25 & 33 \\
varieties (\%) & & & \\
Avg. production of maize per farm (kg)+ & 1580 & 640 & $1146(940)^{* *}$ \\
Yield of hybrid maize $\left(\mathrm{t} \mathrm{ha}^{-1}\right)+$ & 5.06 & 3.99 & $4.85(1.07)^{* *}$ \\
Avg. yield of maize $\left(\mathrm{t} \mathrm{ha}^{-1}\right)+$ & 4.63 & 3.20 & $4.09(1.43)^{* *}$
\end{tabular}

Note: Figure in parenthesis indicates mean difference. ${ }^{* *}$ Significance at $1 \%$ level of significance. + Independent ttest was used. Field survey, 2016

The average yield of maize (both hybrid and Open pollinated varieties) in the study area was $4.09 \mathrm{t} \mathrm{ha}^{-1}$. However, Kavre has significantly higher yield $\left(4.63 \mathrm{t} \mathrm{ha}^{-1}\right)$ compared to Lamjung district $\left(3.20 \mathrm{t} \mathrm{ha}^{-1}\right)$. The hybrid yield in Kavre $\left(5.06 \mathrm{t} \mathrm{ha}^{-1}\right)$ was found significantly higher than Lamjung (3.99 $\left.\mathrm{t} \mathrm{ha}^{-1}\right)$ with an average yield of hybrid $\left(4.85 \mathrm{t} \mathrm{ha}^{-1}\right)$ in the study area. Paudyal (2001) reported the yields of hybrid maize in the mid-hills ranged from 3.80 to $5.06 \mathrm{t} \mathrm{ha}^{-1}$ with mean yield of $4.43 \mathrm{t} \mathrm{ha}^{-1}$. Yields differs significantly across locations may be due to differences in rainfall pattern; crop establishment period; input use; plant population, quality of seed; disease and pest infestation and availability of irrigation (Paudyal, 2000; Shrestha \& Timsina, 2011). Lamichhane et al. (2015) reported 63\% Technology Adoption Index (TAI) of maize in the hilly areas of Nepal, which provides scope for yield improvement of the maize by adopting high yielding varieties along with recommended cultural practices. The average per farm production of maize in the study area was $1146 \mathrm{~kg}$, which was also significantly higher in Kavre (1580 kg) 
compared to Lamjung district $(640 \mathrm{~kg})$. This may be due to higher land allocation for maize production along with higher maize productivity in Kavre compared to Lamjung district (Table 1). None of the maize growers were entered in to contract maize production; they were selling only remaining amount of maize after their use in food, feed and seed. It is common understanding in Nepal that white varieties are used for food and yellow or orange varieties are used for feed purpose but none of the farmers had planned to produce different varieties based on their utilization such as food, feed and seed purpose. However, almost all varieties grown in the study area were in yellow color except Deuti (NMRP, 2015). Yellow maize is grown and consumed worldwide commonly due to availability of provitamin A carotenoids which is not found in white maize (Babu et al., 2013). Paudyal (2001) reported several socioeconomic, environmental, and cultural factors also affect to the selection of maize varieties. Moreover, many other reasons such as productivity level, maturity, foliage quality and quantity, harvesting time and farmer belief about performance of certain varieties also affect the selection of varieties.

\section{Utilization of Maize in the study area}

Farmers were using their maize for different purposes. The utilization pattern of maize varies from place to place based on the food habits of the people (Paudyal, 2001). In totality, $60 \%, 25 \%$ and $3 \%$ of the maize were used for feed, food and seed purpose, respectively in the study area. Whereas the remaining amount of the maize (12\%) were sold to the different buyers. In some cases, $98 \%$ of their production was used as feed. Paudyal (2001) reported about $71 \%$ of maize was used for human consumption in high hills, whereas it was 54 to $73 \%$ in mid hills. However the case was different in Terai as only $27 \%$ of maize was used in consumption, remaining maize was sold to the market (46\%), used as animal feed (15\%), making alcohol (9\%) and kept for seed (3\%). In central terai, major portion of maize (95\%) went to the market and remaining quantity was used for domestic feed (Paudyal, 2001). The result shows that the current situation is completely different than that of 2001 where majority of the maize production has been used in feed rather than in food in hills of Nepal. Moreover, in case of farmers involved in maize Mission Program, 50\% of their production has been sold to the feed industries and remaining $34 \%$ is used for own cattle feed and $16 \%$ as food (CDD, 2011). Study shows lower proportion of maize production in Kavre was used for food purpose compared to Lamjung district, however opposite was the case in feed and sell purpose (Figure 2). CDD reported that maize demand is increased by 300 percent in Kavre from 2006-10 and majority of the maize produced (27375 ton) in the district has been used by the feed industries. In addition to this amount, feed industries has been collected about 18250 ton of maize from other districts usually from Sarlahi and some time from India as well. 


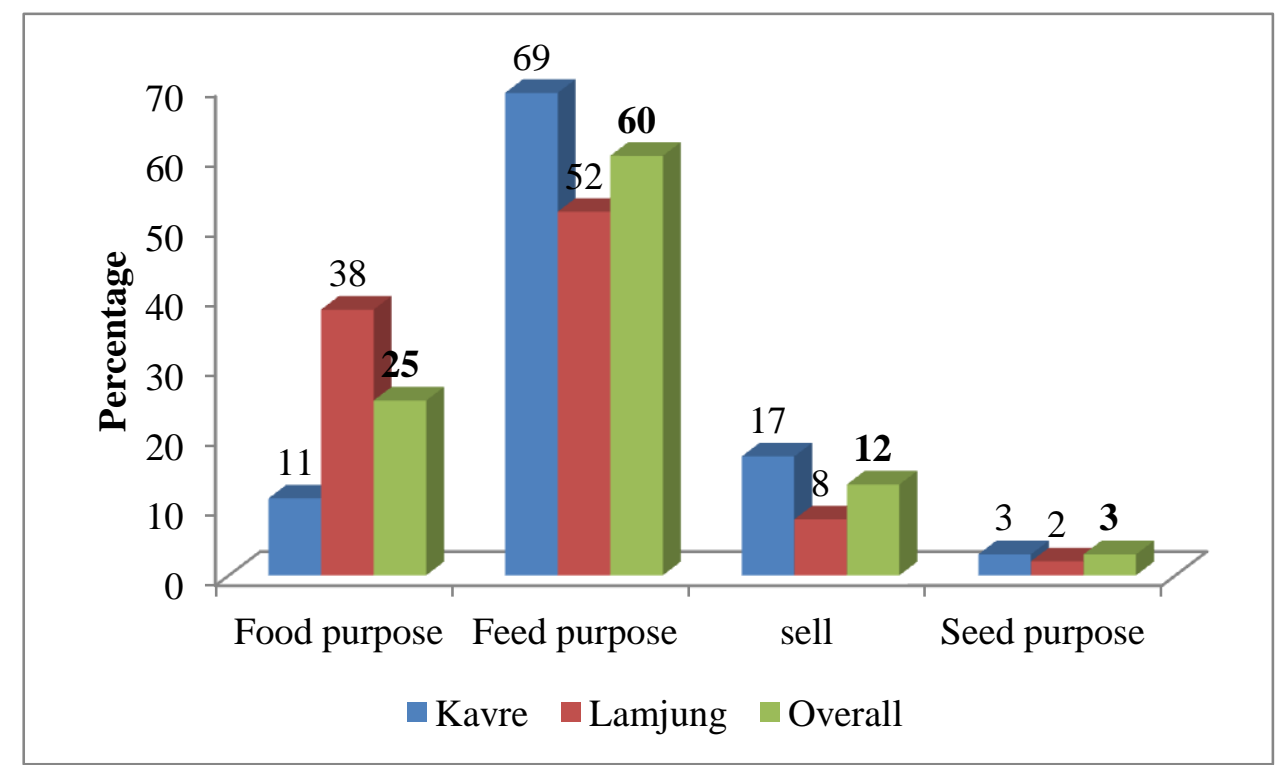

Figure 2. Distribution of maize utilization pattern in the household level (Field survey, 2016).

The proportion of maize feed supply to different animals in the study area was varying. In overall, farmers were supplying higher amount of maize feed per day to cow/s $(2.59 \mathrm{~kg})$, followed by buffalo/es $(2.44 \mathrm{~kg})$, pig/s $(0.73 \mathrm{~kg})$, goat $/ \mathrm{s}(0.71 \mathrm{~kg})$ and chicken $/ \mathrm{s}(0.14 \mathrm{~kg}) . \mathrm{In}$ all animals, the quantity of maize feed supplied to animals was higher in Kavre compared to Lamjung district (Figure 3). This may be due to the more number of livestock animals in the Kavre district where more than $300 \%$ higher number of cattle, buffaloes, goats and pigs compared to Lamjung (MOAD, 2014). This shows that feeding supplied ratio per animal was more or less similar in the study district.

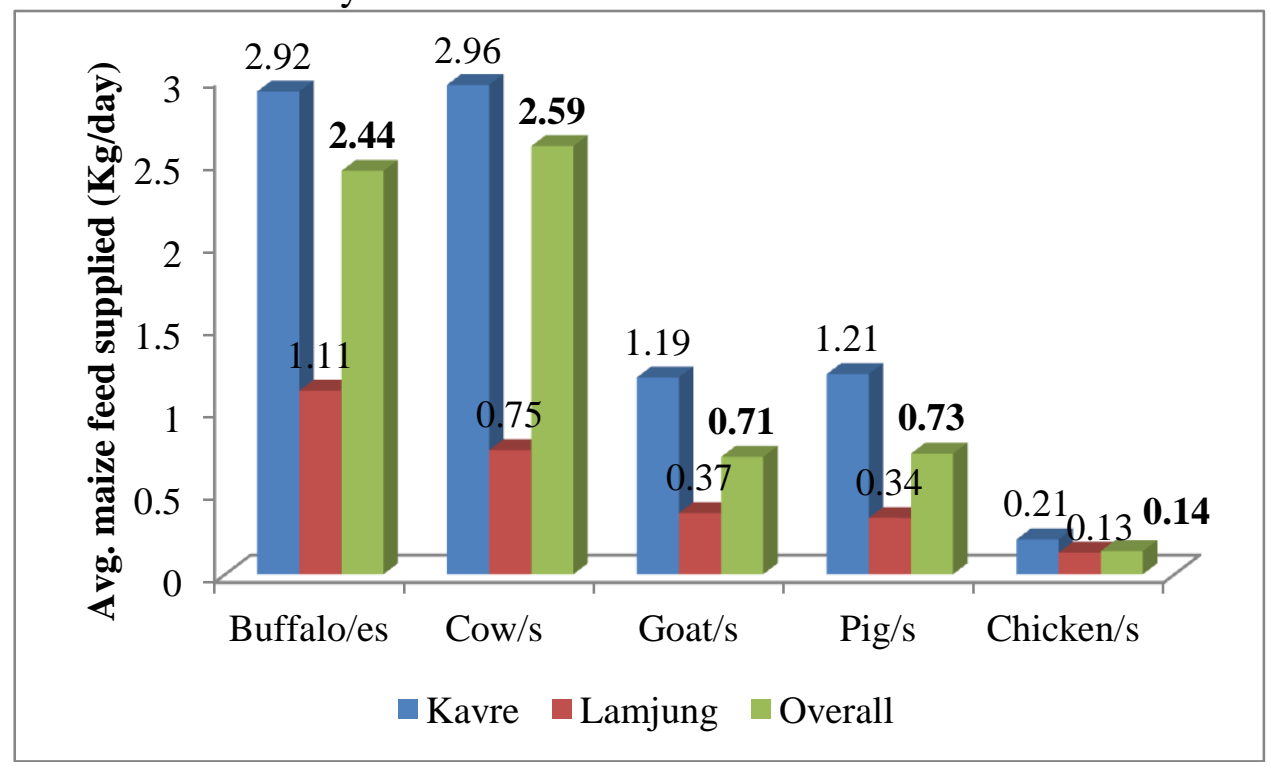

Figure 3. Details on maize utilization as a feed for different animals (Field survey, 2016) 
Journal of Maize Research and Development (2016) 2 (1): 20-29

ISSN: 2467-9291 (Print), 2467-9305 (Online)

DOI: http://dx.doi.org/10.3126/jmrd.v2i1.16212

\section{Maize feed production by feed industries.}

The result shows that average quantity of feed produced by feed industries in the study areas was 22,200 ton per year. They were using an average 12210 ton of maize each year for producing feed. It is estimated that at least 1.5 million tons of maize is required to the existing 114 feed industries in Nepal, which is about the $70 \%$ of the total maize production (2.28 millon t) in Nepal (MoAD, 2014). Our study shows that out of total maize that was used in feed production, $87 \%$ of the maize was imported from India each year by feed industries. Analysis shows negative correlation between scale of feed production and use of domestic maize as a raw material. This is due to unavailability of required quantity of domestic maize in required time. In the domestic maize, usually feed industry has contract with different parties such as traders and farmers. Gurung et al. (2011) reported that feed industries are collecting maize grains from traders $(50 \%)$, cooperatives (35\%) and individual farmers (15\%). Study shows that, up to 7 parties were involved for selling maize to feed industries. The major pre-condition for maize buying was moisture content which must be equal or less than $14 \%$. Very little or no inert materials and physical injury, free from fungal attack and bigger size were also the criteria for maize buying. However, some of the feed companies were also emphasizing on protein and amino acid content. But they were not buying using such criteria. Analysis shows $13 \%$ and $8.5 \%$ increasing demand of poultry feed and animal feed, respectively over the last five year. $60 \%$ of the feed industries do not know about the quality protein maize released by NARC. They were interested to buy Nepalese maize if it would be available in required time and quantity. They suggested increasing commercial production of maize in Nepal through mechanized agriculture and encouraging cultivating maize in barren land. At the same time they also highlighted the importance of awareness creation to famers for increasing maize production adopting improved maize technologies. Establishing and improving maize seed system efficiency is also equally important (Paudyal, 2001; Ghimire, 2003). Moreover, supply of high quality farmer preferred varieties is important to increase efficiency in the seed system through achieving strategic fit in the seed supply chain (Timsina et al., 2016a, Timsina et al., 2016b \& Timsina et al., 2015).

Table 2. Feed production and raw materials use in the feed industries and demand trend of feed over five years.

\begin{tabular}{ll}
\hline Particulars & Magnitude \\
\hline Avg. qty. of feed produced per year (mt) & 22200 \\
Avg. qty. of maize used per year (mt) & 12210 \\
Avg. qty. of imported maize used (\%) & 87 \\
Avg. qty. of domestic maize used (\%) & 13 \\
Avg. demand trend of poultry feed increased over last five year (\%) & 13 \\
Avg. demand trend of animal feed increased over last five year (\%) & 8.5 \\
\hline
\end{tabular}

\section{Field survey, 2016}

Changing context in food habit and its effect on grain utilization pattern

About $6 \mathrm{~kg}$ of plant protein is required to produce $1 \mathrm{~kg}$ of high-quality animal protein (Pimentel and Pimentel, 2003). However, this efficiency varies widely. Worstall (2012) reported about 7 
$\mathrm{kg}, 4 \mathrm{~kg}$ and over $2 \mathrm{~kg}$ of grain required to produce $1 \mathrm{~kg}$ of live weight in cattle, pork and chicken, respectively. Roughly about seven times more energy is required to produce one calorie of chicken than to produce one calorie of maize for human consumption (Alter, 2010). NPC/CBS/WFP (2013) study provides some data comparing food consumption patterns in National Living Standard Survey 2 and 3 in Nepal. It is reported that the households in 2010/11 were consuming a higher quantity of micronutrient and protein rich food items as compared to 2003/04, i.e. consumption has more than doubled for meat and fish, tripled for vegetables, and fish, $40 \%$ increase in potato and over $50 \%$ for oil/ghee, eggs, fruits. In the seven year period from 2003/04, there is significant increase in the consumption of fish, meats, and poultry has been observed. For example, in rural areas in Nepal, consumption of chickens has increased by $180 \%$ since 2003/04. Timsina (2012) reported that from 1990 to 2007, there was increasing demand of more fat containing products rather than cereals in Nepal. It seems that due to changing pattern of food habit in Nepalese people, the demand of maize is growing rapidly to feed animals, as conversion ratio of plant protein to animal protein is low (Pimentel \& Pimentel,2003; Worstall,2012; Economist, 2013).

\section{CONCLUSION}

The maize production in mid-hills of Nepal focusing on its utilization pattern was studied to know the current production and utilization scenarios. Study shows about $50 \%$ of the maize areas were covered by hybrid maize. There was no practice of contract maize production. Major part of the maize production has been used in farmers own animal feeding in the study area which is in increasing trend. The results revealed that $60 \%, 25 \%$ and $3 \%$ of the grain were used for animal feed, food and seed respectively. Whereas the remaining amount of the maize (12\%) was sold to the different buyers. Similarly, feed industry has tremendous demand of maize. Out of total maize that was used in feed production, $87 \%$ of the maize was imported from India each year by feed industries. This shows a big scope to increase domestic production and supply of maize. Analysis shows negative correlation between scale of feed production and use of domestic maize. This was due to unavailability of required quantity of domestic maize in time. Result shows $13 \%$ and $8.5 \%$ per year increasing demand of poultry feed and animal feed, respectively over the last five year. Demand of meat based diet has been increasing in Nepal Moreover, it is reported that the consumers are consuming a higher quantity of micronutrient and protein rich food items compared to last decades in Nepal. In such situation, it is necessary to increase the domestic maize production focusing on feed through prioritizing hybrid maize development and its scaling up.

\section{ACKNOWLEDGEMENTS}

We express our sincere thanks to all the farmers and related stakeholders who participated in the field survey. We highly acknowledge Mr. Sudeep Gatuam and Mr. Ghansham Kandel from SARPOD, NARC for their active participation in collecting, compiling and processing information. The contents are the responsibility of the authors and do not necessarily reflect the views of the NARC. 
Journal of Maize Research and Development (2016) 2 (1): 20-29

ISSN: 2467-9291 (Print), 2467-9305 (Online)

DOI: http://dx.doi.org/10.3126/jmrd.v2i1.16212

\section{REFERENCES}

Alter, L. (2010). Energy Required to produce a pound of food. Retrieved from: http://www.treehugger.com/green-food/energy-required-to-produce-a-pound-of food.html

Babu, R., Palacios, N., \& Prasanna, B.M. (2013). Biofortified maize - a genetic avenue for nutritional security. In: Translational Genomics for Crop Breeding: Abiotic Stress, Yield, and Quality, First Edition. (eds. RK Varshney, R Tuberosa). John Wiley \& Sons, 161176.

Bhattarai, T.C. (2011). Recent demand and supply situation of raw materials for the feed Industries in Nepal, paper presented in mission TST training in Chitwan.

CDD. (2011). Impact of maize mission program, report prepared by Crop Development Directorate, Harihar Bhawan, Lalitpur, Nepal. http://cddnepal.gov.np/downloadfile/Impact\%20Study\%20of\%20Maize\%20Mission\%20 Program_1465464199.pdf (accessed on 27 $7^{\text {th }}$ October, 2016).

Economist. (2013). Livestock: Meat and greens: Retrieved from: http://www.economist.com/blogs/feastandfamine/2013/12/livestock.

Ghimire, Y.N., Pokharel, T.P., \& Khadka, R. (2003). Lessons Learned from the Experiences of the Scaling-up Programme of the Nepal Agricultural Research Council. In: Proceedings of workshop on "Lessons Learned from the Experiences of the Scaling-up Programme of the Nepal Agricultural Research Council", Hill Agriculture Research Project (HARP). Pp.137-144.

Gurung, D.B., KC, D. B., Ortiz Ferrara, G., Gadal, N., Pokhrel S., Bhandari, D. R., Koirala, K. B., Bhandari, B. R., \& Tripathi, M. (2011). Maize Value Chians in Nepal. Paper presented in the 11th Asian Maize Confernece held at China on 7-11 November, 2011.

KC, G., Karki, T.B., Shrestha, J., \& Achhami, B.B. (2015). Status and prospects of maize research in Nepal. Journal of Maize Research and Development, 1(1),1-9.

Lamichhane, J., Timsina, K.P., Ranabhat, D.B. \& Adhikari, S. (2015). Technology adoption analysis of improved maize technology in western hills of Nepal. Journal of Maize Research and Development, 1, 146-152.

MOAD. (2014). Statistical Information on Nepalese Agriculture, Ministry of Agricultural Development, 2014.

MOAD. (2015). Selected Indicators of Nepalese Agriculture and Population. Government of Nepal, Ministry of Agricultural Development, Agri-Business Promotion and Statistics Division, Singh durbar Kathmandu, Nepal.

MOAD/CBS. (2016). Food and Nutrition Security: A Status Report. Reported by Ministry of Agricultural Development and Central Bureau of Statistics to the Food and Agricultural Organizations, Nepal.

NARC. (2016). Newly Released Crop Varieties. Published by Government of Nepal/ Nepal Agriculture Research Council, http://www.narc.gov.np/narc/varieties_released.php (accessed on $24^{\text {th }}$ October, 2016).

NMRP. (2013). Registered maize Varieties in Nepal Up to 2013. Published by Government of Nepal/ Nepal Agriculture Research Council/National maize Research Program, Rampur, Chitwan.

NMRP. (2015). Characteristics of maize Varieties Developed and Released in Nepal (1966- 
Journal of Maize Research and Development (2016) 2 (1): $20-29$

ISSN: 2467-9291 (Print), 2467-9305 (Online)

DOI: http://dx.doi.org/10.3126/jmrd.v2i1.16212

2015). Published by Government of Nepal/ Nepal Agriculture Research Council/National Maize Research Program, Rampur, Chitwan

NPC/CBS/WFP. (2013). Nepal Thematic Report on Food Security and Nutrition. Based on the findings of the NLSS 2010/11. NPC and CBS in collaboration with WFP, World Bank, AusAid and UNICEF. Kathmandu.

http://documents.wfp.org/stellent/groups/public/documents/ena/wfp256518.pdf (accessed on October 28, 2016).

Paudyal, K.R., Ransom, J.K., Rajbhandari, N.P., Adhikari, K., Gerpacio, R.P., \& Pingali, P.L. (2001). Maize in Nepal: Production Systems, Constraints, and Priorities for Research. Kathmandu: NARC and CIMMYT.

Pimentel, D. \& Pimentel, M. (2003). Sustainability of meat-based and plant-based diets and the environment. The American Journal of Clinical Nutrition, 78 (3), 6605-6635.

Pokhrel, T. (2013). Impact of Maize varieties Disseminated in Chitwan, Nepal. Economic Journal of Nepal, 42 (6), 45-53.

Ranum, P., Pena-Rosas, J.P., \& Garsia-Casal, M.N. (2014). Global maize production, utilization and consumption. Annals of the New York Academy of Sciences, 1, 1312.

Sapkota, D., \& Pokhrel, S. (2010). Community based maize seed production in the hills and Mountains of Nepal: A review. Agronomy Journal of Nepal, 1, 107-112.

Shrestha, J., \& Timsina, K.P. (2011). Agronomic Performance and Economic Analysis of Maize (Zea mays L.) under Different Plant Geometry and Nitrogen Rates in Chitwan, Nepal. Nepalese Journal of Agriculture Science, 9, 5-13.

Timsina, K.P., Jourdain, D., \& Shivakoti, G.P. (2016a). Farmer preference for seed quality: A choice experiment with tomato growers in Nepal. International Journal of Value Chain Management, 7 (4), 368-390.

Timsina, K.P., Bastakoti, R.C., \& Shivakoti, G.P. (2016b). Achieving Strategic Fits in Onion Seed Supply Chain in Nepal. Journal of Agribusiness in developing and emerging economies, 6 (2), 127-149.

Timsina, K.P., Ghimire, Y.N., \& Pandey, S. (2016c). Existing modalities of Research and Linkage: A case of vegetable sector in Nepal. Government of Nepal, Nepal Agricultural research Council (NARC), Socioeconomics and Agricultural Policy Research Division, Lalitpur, Nepal.

Timsina, K.P. , Shivakoti, G.P., \& Bradford, K.J. (2015). Supply Situation of Vegetable seeds in Nepal: An analysis from policy perspective. Nepalese Horticulture, 10, 26-36.

Timsina, K.P. (2012). Analysis of Energy Requirements, Food Consumption Patterns and Food Security Situation in Nepal. Report submitted to the School of Environment, Resources and Development (SERD), Asian Institute of Technology (AIT), Thailand. Retrieved from:https://www.researchgate.net/publication/309666566_Analysis_of_Energy_Require ments_Food_Consumption_Patterns_and_Food_Security_Situation_in_Nepal.

Worstall, T. (2012). It Does Not Take 7 kg Of Grain To Make 1 kg Of Beef: Be Very Careful With Your Statistics. Retrieved from:

http://www.forbes.com/sites/timworstall/2012/09/03/it-does-not-take-7-kg-of-grain-to make-1-kg-of-beef-be-very-careful-with-your- statistics/\#18a40d7017b4. 